\title{
Embedded Addiction: The Social Production of Gambling Knowledge AND the DeVelopment of Gambling MARKETS
}

JAMEs F. Cosgrave ${ }^{1}$

\begin{abstract}
This article discusses features of the development of gambling markets, particularly the production of knowledge that interacts with and contributes to the constitution of these markets. While gambling expansion is predicated on the provision of "entertainment," and where gambling is marketed as the consumption of safe risks, there is also the possibility of risky consumption and the production of problem gamblers. The article discusses the knowledge produced around the figure of the problem gambler, and how the figure has been productive in terms of institutional developments. The risks posed by the problematic gambler (e.g., to state-owned gambling enterprises) must be "solved" to enable the legitimization of markets and the ongoing quest for profits/revenues. The paper analyzes knowledge production in relation to contemporary sociological orientations to consumption and risk in late modernity.
\end{abstract}

Keywords: gambling markets, knowledge, problem gambling, addiction, consumption, risk

Résumé. Cet article traite des caractéristiques de développement des marchés de jeux de hasard et d'argent, plus particulièrement de la production de connaissances qui interagissent avec ces marchés et qui contribuent à leur constitution. Bien que l'expansion des jeux de hasard et d'argent se fonde sur l'offre d'un « divertissement », et alors que le jeu est mis en marché comme étant la consommation d'un risque calculé, la consommation à risque et la production de joueurs problématiques restent également possibles. L'article aborde les connaissances produites autour de la figure du joueur problématique, ainsi que la mesure dans laquelle cette figure a pu être productive relativement au développement des institutions. Les risques que pose le joueur problématique (par exemple, pour les entreprises de jeux de hasard appartenant à l'État) doivent être « résolus » afin de permettre la légitimation des marchés et la recherche continuelle de profits ou de revenus.

1. The author thanks the anonymous reviewers at CJS for their thorough attention and suggestions for improving the article. 
Le document analyse la production de connaissances en situant cette production par rapport aux orientations sociologiques contemporaines de la consommation et du risque dans une modernité avancée.

Mots clés: marchés de jeux de hasard, connaissances, jeu problématique, dépendance, consommation, risque

\section{INTRODUCTION}

$\int$ last he rapid expansion of gambling enterprises in North America in the last four decades, particularly the spread of casinos, forms of electronic gambling, and Internet gambling since the early 1990s, points to significant developments in consumption activity, and to issues related to the state legitimation of an activity that was previously (officially) deemed problematic for society, and which, in some of its forms, holds certain risks for participants. While there continue to be social conflicts over the implementation and expansion of certain types of gambling e.g., video lottery terminals (McKenna 2008), and the issue of whether jurisdictions should follow the casinos as public policy/economic development route - gambling is largely accepted, and is mass-marketed by private gambling enterprises and states as an entertainment activity.

A particular issue that needs to be addressed in the sociological study of gambling consumption is how gambling has come to be stimulated as an object of consumption, and how markets themselves are developed, maintained, and undergo innovation. These aspects are all too often taken for granted in economic analyses that focus on individual or "consumer choice," where the consumer is "the fictive consumer of economic models, the aggregate of desocialized, individual, rational choicemakers," and where the existence of gambling markets is accounted for, seemingly straightforwardly, by the forces of supply and demand (Miller 1995:17).

Much has been written on the economics of gambling (Clotfelter and Cook 1989; Eadington 2002; Grinols 2003), gambling and social policy (Derevensky et al. 2003; Eadington and Cornelius 1997; Goodman 1995; Whyte 2003), gambling and the law (Dixon 1991; Rose 2003), and gambling addiction (Dickerson 2004; Lesieur 1984; Peele 2003; Shaffer 2003; Steel and Blaszczynski 2002). In relation to addiction, psychological research, with its interest in the fairly new "problem" and "pathological" gambler (Castellani 2000) has overshadowed sociological and cultural studies analyses, although it has been proferred that sociological interest in gambling has been slower to develop (McMillen 1996; Volberg 2008). 
Journals with a specific focus on gambling, such as Journal of Gambling Studies and International Gambling Studies, tend to be dominated by a focus on gambling behaviours and problem gambling, rather than sociological or cultural-symbolic issues. Following on some recent work that argues for more sustained sociological attention to gambling (Bernhard and Preston 2007; Cosgrave 2006), this discussion focuses on the institutional frameworks within which gambling enterprises have developed and in which gambling activity occurs. In particular, the discussion draws upon contemporary developments in sociology to focus on the production of gambling knowledge. While "problem gambling" is discussed here, the focus is on how this classification/construct relates to and contributes to the development of gambling markets and to other institutions, including the state. The interest is to see how the problem gambler is institutionally productive, contributing not just to the gambling money/revenue economy, but also, and more interestingly, to knowledge economies and institutional development.

The problem of the problem gambler (whether termed addiction, pathology, loss of control, disordered gambling), the topic of so much research in academic gambling journals and in institutionally funded gambling research (Shaffer 2007), has become a highly productive discursive object, and is not really a problem to be solved so much as a risk to be managed. To say this is not to ignore the important work and empathy of counselors and clinicians who deal on the front line with individuals who are concerned about their excessive gambling, and who have created hardship for themselves and their families.

The interest of this discussion is to see how this object acts like a discursive pivot around and through which knowledge fields are constructed, producing institutions and agencies, and new areas of research, thereby also contributing to the legitimation and expansion of gambling markets. In relation to the development of these markets, psychological research on gambling problems acts as a de facto form of consumer market research. The construction of the addicted or pathological gambler serves to modulate gambling offerings and is embedded in the knowledge producing economy. The development of gambling markets provides an occasion then, not only for the analysis of processes of "making up people" (Hacking 2002) but of the making of institutions and forms of state conduct.

This discussion draws upon the work of Michel Foucault (1977; 1991), Foucauldian governmentality analyses, and contemporary sociological formulations of risk to consider the constitution of gambling markets and the knowledge production that is generated. The development of institutions and knowledge is of interest to the sociologist, making the 
discursive field itself a topic. A guiding concern is: how are gambling risks constructed and embedded in the field of knowledge, and how does gambling knowledge relate to the development of gambling markets?

\section{Consumption AND Risk}

Legal gambling activities are a form of consumption whereby actors demonstrate orientations to pleasure, desire, and leisure in the "consumer society" (Campbell 1987; Hannigan 1998; Kingma 1997). While the classical sociological emphasis on production has been displaced by an analytical emphasis on consumption for theorizing about the social organization and culture of (late) modern societies (Baudrillard 1975; 1988; Bauman 2001; Miller 1995; Ritzer 1999; 2005), analysts of late modern society have also provided formulations of risk for an understanding of contemporary social organization (Beck 1992; 1995; 1996; Giddens 1990; 1991; Lupton 1999; Lyng 2005).

In contrast to the earlier macro formulations of the risk society (Beck 1992), more recent micro accounts of risk provide analyses of risk-taking, theorizing it as something desirable for the actor. Giddens (1991), for example, discusses "cultivated risk," Gephart (2001) discusses "safe risk," and Lyng discusses "edge-work" (2005). While risk-taking commodities are now offered in tourism and leisure markets (Gephart 2001; Hannigan 1998), the pursuit of risk is understood by these analysts to be an expression of social transformation and changing social structure. Gephart (2001:141), for example, considers "safe risk" as a "foundational organizational feature of contemporary spectacular society," while Lyng (2005:8) suggests that risk-taking is a "structural principle" of actor and institutional orientations in "risk societies."

The legalization and expansion of gambling has liberalized a form of risk-taking that was previously held (at least officially) to be problematic for society. In a liberalized environment, indeed within a larger cultural milieu where consumption is central to social organization, participation in risky practices and the consumption of risk products is not so much the issue, but excessive or unsafe involvement entails certain kinds of stigmatization, such as the label of addiction (Cosgrave 2008).

Casinos are sites of spending experience, and as providers of opportunities for pleasure and expenditure, their expansion in the contemporary legalized gambling environment is illustrative of the transformation of economic ethics, cultural values, and socialization processes in the shift from industrial to postindustrial consumer societies (Cosgrave and Klassen 2001; Miller 1995; Tucker 1991; Weber 1958). It is in relation 
to the development of the latter that orientations to risk and risk-taking require consideration. While the analytical status of risk in rationalized and commercialized gambling venues is subject to debate (Lyng 2005), the consumption of risk is what attracts gamblers. In its mass-marketed expressions, gambling is advertised as a form of "entertainment" and casinos are represented as sites for the consumption of "excitement" (e.g., the slogan for Ontario's Casino Rama, run by the Rama Indian Band is "We deal Excitement Big Time!").

Where the consumption of risk is motivated by the positive features of risk-taking - the thrills of sky-diving, the excitement of gambling, the highs of drug-taking (Goffman 1967; Lyng 2005; Reith 2005), risky consumption is consumption with unwanted risks. Gamblers do not desire to be addicted, sky-divers seek to master the details of their activity and avoid disaster, and drug users do not want to overdose.

The consumption of risk as we find in gambling, or in other forms of "edgework" (Lyng 2005), is now a significant feature and driver of consumer markets, but consumers are warned by providers and public health agencies that involvement in such activities should not become risky or potentially dangerous consumption for them. Consumers are given the message of responsible consumption, which acts, (in the case of responsible gambling instructions for example), as a pedagogy for behaviour.

Legalized commercial gambling enterprises market the consumption of risks as entertainment, often downplaying the ways in which gambling becomes risky consumption. Nevertheless, problematic forms of gambling become an object of risk management for gambling providers. The development of gambling markets requires the stimulation of consumption (of risks) as well as the stimulation of knowledge generated to manage the unwanted risks of excessive consumption. This dynamic of knowledge generation contributes to institutional development, raising significant problems for gambling providers and revenue beneficiaries, particularly when gambling markets are stimulated by state-owned gambling enterprises.

Studies of gambling in many jurisdictions reveal the high proportion of gambling revenues generated from a small number of gamblers (Livingstone and Woolley 2007; Productivity Commission 1999; Volberg et al. 1998; Williams and Wood 2004; 2007). Rates of problem and pathological gambling measured through prevalence studies typically range from 1-6\% (pathological gambling rates comprising a lower percentage than problem gambling rates in any total percentage number), with higher rates for youth and aboriginals (Derevensky 2009; Wardman et al. 2001). Such rates do not seem at all morally problematic to the states and governments that own or are the financial beneficiaries of 
gambling enterprises, and that commission these studies, as excessive gamblers are typically viewed (officially) as the casualties of legitimate gambling as a consumer choice (Borrell and Boulet 2007; Livingstone and Woolley 2007; McKenna 2008). The disease model of (excessive) gambling - which has generated the category of "pathological gambler" (Castellani 2000) - discursively serves this perspective, positioning the problematic gamblers in a statistically "small" group of flawed individuals. However, the high proportion of revenues generated by such gamblers (not to mention the production of such gamblers in the first place) may pose serious legitimation problems for the state. Research on problematic gambling thus becomes an object of consumption and expenditure for states (e.g., state gambling research agencies) and industry, and contributes to the constitution and shaping of gambling (consumption) markets (Borrell and Boulet 2007; Mun 2002).

Gambling enterprises have to reflexively manage and monitor risky consumption as a way to provide safe (risk) experiences and to enable market involvement and expansion (Gephart 2001; Kingma 2004; Mun 2002). While these enterprises claim to strive to limit and avoid the occurrence of risky consumption, such consumption is, paradoxically, a productive feature of the development of markets.

\section{The Problematic Gambler and Gambling Markets}

The biggest problem for legalized gambling and its expansion, and most certainly for state-owned gambling enterprises, is the problematic gambler. Such a gambler is a risk to gambling enterprises in a number of ways: they are the negative outcome of legalized and expanded gambling (although they are said to be relatively few in percentage terms) and cannot gamble "safely," hence requiring education, treatment, or therapy. This risk-aspect is usually handled by the spending of money (by governments for example) on problem gambling programs, counselors, agencies, and the production of problem gambling research. However, such gamblers can pose a serious risk to gambling providers, not only by prompting concerns about the production of harm, but by threatening the legitimacy of gambling enterprises themselves, and the policy and ethical discourses that support that legitimacy (Borrell and Boulet 2007). It is important then to consider the production of knowledge around this figure, the forms of risk management, and the integration of this figure into the gambling economy.

In his analysis of the category of "pathological gambler" Alan Collins discusses its late emergence: 
... it is worth pausing to consider whether or not the lateness of the pathological gambler was in fact due partly to gambling itself only becoming constructed as a fully fledged object of government rather late on. Despite the history of legislation in the $19^{\text {th }}$ century, gambling may not have been governable in the strictest sense.... What was missing ... were numbers, statistics, charts, graphs and other physical inscriptions of the gambling population. Until the late $20^{\text {th }}$ century the means of assessing extent of gambling were not in place: its illegality made much of it hidden, the informal and secretive nature of many gambling forums made them extremely difficult to assess, there were the thorny issues of defining gambling, and perhaps most importantly of all, there was the technical problem of distinguishing money new to the gambling market from money being recycled within the market. (Collins 1996: 93)

Along with the recent legalization and rapid expansion of varieties of gambling in the past forty years has come the proliferation of gambling knowledges, especially since the 1990s. According to problem gambling researcher Howard Shaffer,

By the end of the twentieth century, almost $50 \%$ of gambling studies journal articles had been published during the 1990s. Now, almost $33 \%$ of gambling studies journal articles have been published between 1999 and 2003. (Shaffer 2004)

This concerns academic writing on gambling, but there is also the knowledge produced from consumer behaviour and market research perspectives by private industry and state gambling corporations and agencies interested in maintaining and creating gambling markets.

The 1990s saw the introduction of casinos and electronic gambling machines (EGMs) in many jurisdictions, and gambling activity has now been brought out into the open in three senses:

1. the legalization and liberalization of gambling has allowed gambling to be public (overt), and with liberalization the stigmatization has been largely overcome;

2. the commercial interests of private gambling enterprises and revenue interests of states have created large gambling markets, both legal and illegal, which must now be considered global in scope; and

3. problem and pathological gambling are a product of this expansion, most notably in relation to EGMs (Smith and Campbell 2007).

The visibility of gambling and the commercial, capitalistic interests in the activity have produced varieties of gambling knowledge that seek to generate, as well as understand and explain, gambling behaviours in the context of the constitution of commercial markets. We can speak here of the fields of knowledge production framed by the opening up of 
these markets. The visibility of gambling allows the visibility of various objects, one being the problematic gambler, which, as presented here, has and continues to be a highly productive object of knowledge. It is significant that EGMs have generated a large proportion of gambling research, as they have come to be regarded as the riskiest form of gambling from an addiction perspective (Cox et al. 2005; Livingstone and Woolley 2007; Smith and Campbell 2007). For Livingstone and Woolley (2007:369),

Gamblers are not powerless to resist the enticements of EGMs, but EGM games have been scientifically developed to attract gamblers, reconfigure their agency, and maximize their expenditure. Excessive levels of harm production are in our view a concomitant of this.

While the type of addiction related to these machines - stimulated by operant conditioning - is not new, the machines differ from older slot machines in their technological sophistication, providing "an unsafe mode of rapid and expensive consumption" (Livingstone and Woolley 2007:369).

As these machines are highly profitable, there has been great resistance on the part of the gaming industry and states to abolish them (Smith and Campbell 2007; McKenna 2008). One version of the production of knowledge related to these machines has focused on their modulation, to make the machines themselves more "responsible." Some machines now include "responsible gaming features" that allow the player to more directly control their own involvement (such as being able to set time and financial limits). Despite the evidence singling out EGMs as the primary gambling addiction culprit, a consequence also of the prevalence and availability of this form of gambling in many jurisdictions (Smith and Campbell 2007), discourses about gambling behaviour problems wrestle with the source of the problems - is it to be located in the highly addictive technological constitution of the machines (where anybody can become an "at-risk" gambler), or in faulty or diseased individuals (Dickerson et al. 2003; Livingstone and Woolley 2007; Reith 2007)? In the case of EGMs, perhaps it inheres in between, in a new behavioural space produced by sophisticated gaming technology? Competing epistemologies shape the gambling field (McGowan 2004), and in terms of the development of gambling markets, the issue here is: how do these epistemologies and definitions of gambling problems interact with the profit/revenue motive of gambling markets? How do they enable forms of governing? 


\section{Producing Knowledge, Governing Gambling}

In his ground-breaking study of punishment and social control, Foucault (1977) provided a novel understanding of delinquency and how it provided an object of social control for authorities. In effect, the delinquent was produced by the system of punishment (contact with prison), and made useful to social control through various means. The delinquent was a product of the penal system (Foucault 1977). This argument has some bearing on what is being discussed here: the problem gambler is a product of gambling enterprises, and while potentially a legitimacy risk for gambling enterprises, nevertheless enables institutional development, the production of expertise, and modes of knowledge that seek to govern the behaviour (Castellani 2000).

More recent work has drawn upon Foucault and governmentality approaches to offer accounts of the social production of the pathological and problem gambler (Castellani 2000; Collins 1996; Reith 2007). In her genealogy, Reith (2007) points out the rationalist assumptions underlying psychological attempts to understand and explain the problem gambler. She points to the tensions produced between the "consumer sovereignty" of the autonomous, rational Western subject and the problem gambler. The image of the autonomous, rational subject may be the grounds for contemporary psychological conceptions of self, providing an epistemological underpinning for the notion of the "self-governing consumer" (Reith 2007; Venn 1984). However, aside from conceptions of irrationality said to be residing in the problem gambler (Delfabbro 2004), analyses of consumption and the development of consumer markets would reveal, not an ideal-typical sovereign, "rational" actor, but the ways in which the "consumer" is constituted and acted upon through social processes and forms of knowledge. In other words, such analyses would take into account the ways in which the production of consumption activities are predicated on the stimulation and eliciting of desire (Bauman 2001).

The actions/behaviours of actual gamblers are produced in gambling venues that comprise the gambling markets. As suggested by Collins in the passage quoted above, a genealogy of the pathological gambler as classification or type becomes visible with the expansion and development of legalized gambling markets. In his analyses of processes of normalization, Foucault (1977) did not assume a "normal" self, but rather examined these processes and their relation to the production of subjects. Similarly, if a "normal" gambler exists it should be seen - or become visible - in relation to gambling markets, rather than just being assumed to exist. Constructs of the gambler are produced in relation to the know- 
ledges and practices that constitute gambling markets. In their discussion of the conceptual field that constitutes EGM gambling, Livingstone and Woolley (2007:364), remark that this field

discursively constructs problem gambling as an innate human quality, ignoring the behaviour-shaping capacities of sophisticated technologies and practices... This discursive formation produces a hypothetical 'deficit', the difference between a pathologized 'problem gambler' and an ideal type 'recreational' gambler.

That the larger portion of gamblers, according to official gambling agencies, do not develop a gambling problem (as measured and reported in problem gambling prevalence studies), and orient to their gambling as entertainment, treats the "normal" handling of gambling as self-evident (Livingstone and Woolley 2007). However, such statements - which must be appreciated as gambling pedagogy for newly recruited and existing gambling consumers - are significant for their governmental import: as ideals the gambling subjects should strive to corroborate in their behavior (Hacking 2004).

The development of gambling markets includes the constitution and regulation of gambling enterprises and activities, and incorporates the forms of knowledge produced to understand activities and behaviours. These are expressions of "power-knowledge," contributing to forms of governing (Castellani 2000; Collins 1996; Foucault 1977; 1991; Rose 1996; 1999). A governmentality approach challenges the economic model of the "sovereign consumer" underlying the epistemologies that support gambling markets. Here it is not only a question of studying how the marketing of gambling affects attitudes and dispositions, or influences consumer choice, but how the production of knowledge constitutes subjects and reflexively shapes and structures the development of markets themselves. A feature of this process is what Hacking (2004) terms "dynamic nominalism," which refers to the social processes through which selves interact with institutional classifications and categories. The actors' acceptance of classifications in turn has dynamic effects on the classifiers' knowledge. The institutional and expert interpretations of behaviour provide the discursive frameworks individuals use to "understand" their own behaviour (Hacking 2002; 2004). Added to this dynamic are the ways in which the classifications and categories extend the scientific field by attracting researchers and research money, contributing further to institutional development and prestige.

From this perspective gambling addiction has been very productive. Addictions are certainly economically productive: alcohol and tobacco addictions generate huge profits for their producers and even for their 
regulators, the governments that reap the taxes. The problem and pathological gamblers are economically productive as many studies have shown (Livingstone and Woolley 2007; Volberg et al. 1998; Williams and Wood 2007). For this discussion "problems" are also productive because they contribute to the constitution of fields: the various experts and knowledge producers (psychological and otherwise), the development of research agencies and institutes that expand and deploy knowledge, the uses of knowledge by counselors and the creation of treatment approaches.

As the development of gambling markets requires the stimulation and integration of gambling behaviours, the production of front-end and back-end knowledges can be distinguished. Front-end knowledge relates to the revenue (or profit) imperative and the stimulation of gambling behaviour, including excessive gambling, in relation to this: gambling marketing and advertising, casino construction (its external construction, and more importantly its internal environment), the design of games and their technological appeal, physical access to gambling - all forms of knowledge that contribute to the generation of revenues. Back-end knowledge refers to the forms of knowledge related to the management of gambling behaviour and any negative consequences or "bads": problem gambling knowledge used by counselors and treatment centres, public relations strategies to shape public opinion and manage risk controversies, strategies produced to appease gambling expansion or opposition groups, and also criminal enforcement knowledge.

Ritzer's (2005) conception of the "means of consumption" is useful here as it points to the ways in which gambling activities are structured as legal and rationalized forms of consumption. Casinos are highly rationalized consumption sites, where we find particularly strong examples of both enchantment, the way in which the setting constructs inducements to spending and the lure of winning, and surveillance - the all pervasive "eye in the sky." It should also be pointed out how other modes of casino surveillance, through the use of player loyalty programs, for example, track consumer expenditure and behaviour. While front-end gambling knowledge is an obvious and central feature of the means of gambling consumption, this discussion points to the ways back-end knowledge is important for the management of risky consumption, which may pose legitimacy problems for gambling providers. For Ritzer, the "means of consumption" refers not just to the structuring of the consumption setting, but also to the ways in which "people are controlled and exploited as consumers" (Ritzer 2005:50).

Gambling expansion is producing behaviours, both problematic and unproblematic, and the generation of front- and back-end knowledges 
is central to a risk management orientation, where risk is not just something (negative) to be managed, but something productive:

Rather than being a programmatic failure or a source of resistance to be overcome, risk represents an opportunity for governmental expansion, refinement and modification. Concrete indicators of risk such as revenue audits and rates of pathological gambling ... allow the state to judge the level of activity of these economic and social risks, which subsequently empowers it to improve upon its performance of casino provision. (Mun 2002:229-230)

There are, then, the knowledges that seek to liberate or produce gambling behaviour, and knowledges that aim to regulate such behaviour, particularly the negative manifestations. The production of knowledge (both front- and back-end) contributes to the governing of gambling behaviours, as the consequences of the liber(aliz)ation of gambling are not known in advance. The unintended consequences of liberalization and market expansion point to the reflexive production of risks; this production generates knowledge about gambling behaviour (the discursive field), and contributes to the development of markets.

The production and visibility of behaviours are the consequence of knowledge that has already shaped gambling enterprises. These behaviours may require further governing practices as they manifest themselves (in unwanted ways) and as new front-end knowledges are introduced into gambling markets. Such behaviours result from interactions between gamblers, the games themselves, and the gambling venues or environment (casinos, racinos, bingo halls, video lottery terminal sites, internet gambling, etc.). Programs directed at individuals' gambling behaviours, such as "self-exclusion programs" and "responsible gambling" (the latter discussed in the next section) are generated, relate to, and serve both (front and back) ends. They are aimed at governing the conduct of gamblers.

In relation to the building of gambling markets, the following comments by Rose (1999:245) are instructive:

... the commoditization of consumer preferences may generate new forms of visibility of the attitudes, aspirations and desires of citizens ... to assemble the subject of consumption: to render the consumer knowable and calculable within an economy of desire, to construct relays and relations between the predilections and passions of the individual and the attributes and image of the product.

Thus, in the relationship between knowledge production and gambling markets, along with dynamic nominalism there is also dynamic behaviourism. 


\section{The State, Gambling Consumption, and Risk Management}

The notion that risk-taking is a "structural principle" of actor and institutional orientations in "risk societies" suggests that this principle also applies to and influences the conduct of the state (Lyng 2005). However, as states must respond to political pressures and legitimacy concerns, the management of risk is a central objective of contemporary state activity (Beck 1992). It is also significant that states have played a major role in the current climate of legalized gambling, not only through their obvious legal powers, but, in many jurisdictions, through their interests in revenue collection, if not their outright ownership of gambling enterprises themselves. State ownership of gambling enterprises, (such as we find in the Canadian provinces, or in the Netherlands and other countries), is itself a form of economic risk-management, an example of entrepreneurial revenue seeking when other traditional forms of taxation are either shunted aside or not viewed as feasible. This ownership model also often rests on a claim to be able to successfully risk manage the integrity of gaming enterprises and products themselves, for example, by taking them out of the hands of criminals. However, there are greater risks to the legitimacy of state-owned gambling enterprises.

In Canada, gambling enterprises are owned and overseen by the various regional and provincial gambling corporations, such as the Ontario Lottery and Gaming Corporation. Commentators have pointed to the inherent conflict of interest for governments - as both regulators and promoters (and main beneficiaries) of gambling activity (Campbell et al. 2005). This is also significant since, not only do states take an active role in promoting particular types of consumption, they must manage the risks that arise through their involvement in markets. These risks include legitimacy risks which stem from the view that the state is producing problem gamblers, and that state involvement in gambling enterprises may be morally questionable (Campbell et al. 2005).

Where Beck has framed his theorizing on risk largely in terms of societal formulations of, and responses to, ecological risks, there are also the risks related to and produced by consumption (Beck 1992). Beck has discussed such phenomena as BSE (bovine spongiform encephalopathy), which relates to consumer demand for beef (Beck 1996). In the consumer society, many kinds of risk are generated in relation to societal emphases on health and safety (see, e.g., Gephart 2001; Giddens 1991). The development of gambling markets provides a pertinent illustration of the production of risks - how they are constructed and managed. This is not to suggest only a negative conception of risk, but rather also the ways in which risks are productive (Mun 2002; Rose 1999). 
The high proportion of revenues generated by problem gamblers may pose serious legitimation problems for the gambling state. How can problem gambling be managed without posing a major legitimacy threat to state involvement? It is curious that so much gambling research is oriented to this "small" percentage of gamblers, although the percentages can represent tens or hundreds of thousands of actual people with gambling problems in a jurisdiction. In part, this reflects the initiatives of states to sponsor research (such as prevalence studies) on the social impacts of gambling expansion, which is nevertheless a risk-management strategy. Further, much as numbers can conceal, they can also be revealing, especially here since this small percentage of gamblers generates so much of the gambling revenues. How is this tension modulated?

The solution exists at the back end, with governments slotting a certain portion of gambling revenues to education and treatment, as well as ongoing research. The concept of "safe risk" (Gephart 2001) not only refers to the organization of the venues for (safe) risk-taking and consumer expectations of provider integrity, it may now be extended to the idea that even addictions can be managed - through state expenditure on programs and the production and application of scientific knowledge.

In the province of Ontario, $2 \%$ of slot machine revenues are set aside for gambling addiction programs (Williams and Wood 2007). In their discussion of the EGM industry in Australia, Livingstone and Woolley (2007:362) refer to "the comfortable orthodoxy ... which, while not denying problem gambling, exclude(s) upstream issues of harm causation from discourse while privileging downstream treatment-based responses." The money spent on research at the very least provides governments with a veil of knowledge, giving the impression that "they are doing something to help these people," who nevertheless remain extremely good business for states and the gambling industry (McKenna 2008; Smith and Campbell 2007).

In Canada, problem gambling programs and research institutions, such as the Ontario Problem Gambling Research Centre and Alberta Gaming Research Institute, are funded by gambling revenues. The production of gambling knowledge is also generated by North American university research programs devoted to gambling addiction research, such as McGill University's International Centre for Youth Gambling Problems and High Risk Behaviours and Harvard University's Institute for Research on Gambling Disorders, affiliated with Harvard Medical School.

In relation to the privileging of the "downstream" orientation to problem gambling, questions also arise with gambling research funded by gambling revenues, since clearly the revenue interest of gambling 
stakeholders is primary; gamblers and problem gamblers thus simultaneously contribute to revenue generation and the production of knowledge about them. Here we see the merging of front- and back- end gambling knowledge. In terms of the relationship between forms of gambling knowledge and the development of gambling markets, Borrell (2008:206) draws attention to the "industry-funded National Council for Responsible Gambling (NCRG) which has commissioned Harvard Medical School's Division on Addiction to research gambling pathology to the tune of millions of dollars." She points out that the NCRG exists to "identify problem gambling as a pathology," thus conceptualizing pathological gambling "as an individual disorder" (Borrell 2008:207). At work here is a particular discursive representation of gambling problems, a revealing example of the relationship between the production of gambling knowledge and gambling market interests.

Increasingly the risks associated with gambling participation, EGMs in particular, have produced calls for more consumer safety features in gambling products and venues. Different jurisdictions have different gaming and EGM policies; EGMs are a widespread form of gambling, and in Western countries slot machines are the bread and butter of casino gambling, generating the bulk of revenues. Depending on the policy configuration (where there are differences, not only between countries, but between provinces and states) EGMs may exist in public areas, such as bars, lounges, arcades, airports, grocery and convenience stores (Smith and Campbell 2007); in North America, they have also become central to the "racino" - a horse racing venue with slot machines. While some jurisdictions (such as the provinces of Ontario and British Columbia) only permit EGMs in casinos, the concern with their location outside casinos is their accessibility, making them a form of "convenience gambling." What is significant for this discussion is how the interest in and concerns with "safer risk" stem from the interactional dynamic of actual gamblers with particular games and in particular venues or settings. Dynamic behaviourism thus appears here in the relationship between the potential for excessive gambling and the provider desire for more profit, a relationship that needs to be finely tuned.

Despite the calls for greater gambling safety features in North America and elsewhere, the risks of gambling participation devolve upon the individual. This has been characterized as being in keeping with the climate of economic neoliberalism where market relations are conceived as the basis of social relations (Cosgrave 2006; Reith 2007). In the environment of legalized and expanded gambling, earlier moral stigmas attached to gambling such as sin and vice weaken; however, morality does not disappear, it is defined as personal responsibility (Ewald 2002; 
Rose 1996). This is demonstrated in official calls for the responsible consumption of practices and goods, such as "responsible gambling" (Responsible Gaming Council Ontario 2002). It is largely aimed at the individual consumer of gambling activities, and is a form of governing of gambling behaviour.

Some of the epistemological tensions between forms of gambling knowledge should be pointed out, for example, between the discourse of "pathology" and the discourse of responsibility. In contrast to the notion of gambling pathology, which is grounded in a medicalized disease framework (Castellani 2000), the official notion of responsible gambling implies that anyone is "at risk" of becoming a problematic gambler. The responsible gambling programs inserted into gambling markets, including literatures that provide the know-how for "responsible" orientations to gambling, imply that there is really no "normal" gambling - responsible gambling has to be taught to the prospective gambling consumer. The various discourses about gambling become ways in which gamblers can reflect on their self-image and understand their own orientations. Responsible gambling is thus an ideal to which gamblers should aspire.

The languages of pathology and responsibility are discursive framings of gambling behaviour that contribute to the constitution of gambling markets. As gambling addiction becomes a phenomenon of risk management, it becomes an object of both state and industry consumption; gambling knowledges are produced and new institutions for the study of behaviour develop (Castellani 2000; Collins 1996; Hacking 2002, 2004).

\section{Conclusion}

This discussion has examined how developments in the gambling field illustrate developments in late modern consumer society: as gambling is colonized, commercialized, and expanded, the normalization of the market and management of risks that arise require legitimation strategies, forms of knowledge, and consumer research. From a governmentality perspective, the discursive links between gambling research and consumer behaviour and market research become fruitful objects of analysis themselves, as those within the field interested in the "relays and relations

2. It's Only A Game: The Responsible Gambling Handbook includes such gambling lessons as these: "gamble for entertainment, not as a way to make money"; "balance gambling with other leisure activities"; "set a limit and stick to it - if you've lost the money you budgeted for gambling, stop"; "if you're losing, don't chase your losses accept any loss as the cost of your entertainment"; "always set a time limit" (Responsible Gambling Council Ontario 2002). For a discussion of orientations to "responsibility" in contemporary Western neoliberal milieux, see Reith (2008). 
between the predilections and passions of the individual and the attributes and image of the product" produce knowledges that contribute to the shaping of gambling markets (Rose 1996; 1999). Addiction research becomes significant as a branch of consumer research through the production of knowledge generated in relation to forms of risky consumption.

In his formulation of the life of contemporary consumption, Bauman (2001) conceives it as unconstrained and anomic, having no greater purpose than its own perpetuation. The transcendence supplied by society (analyzed by Durkheim) has all but vanished, as individuals pursue their own desires and wishes. Consumption appears to be morally deregulated. While gambling "liberalization" suggests a shift in the interpretive framing of gambling activities away from moralized definitions (e.g., as $\sin$ or vice), to be noted is not the absence, but the transformation of moral discourse. Moral concerns around gambling persist, enacted through discourses of personal responsibility. Such discourses play an important role in the development of consumer markets where the consumption of risks is central to the consumption activity. They also serve as legitimation devices for gambling providers, such as the state, in their desire to manage risk-downloading onto gambling consumers. In serving to perpetuate consumption, they seek to govern the individual who wants to participate in legal, commercialized, gambling activities.

Addiction may be viewed as a consequence of social orders that promote "unconstrained" consumption - a phenomenon deserving analysis in relation to the notion of a diminished "social." It is nevertheless crucial to examine the forms of knowledge generated to produce, govern, and profit from desire. While problematic gambling is conceived as a social problem requiring solutions, the development of gambling markets reveals how addiction has become an object of consumption and knowledge through state and research expenditures, and institutional developments that contribute to the visibility of gambling behaviours. Addictive behaviours may not be explicitly solicited by commercial gambling providers, but gambling addiction itself has now become a central discursive object, embedded in the field of gambling knowledge, contributing to the constitution of legalized gambling markets.

\section{REFERENCES}

Baudrillard, Jean. 1975. The Mirror of Production. St. Louis: Telos. [1970] 1988. The Consumer Society: Myths and Structures. London: Sage.

Bauman, Zygmunt. 2001. Consuming life. Journal of Consumer Culture 1(1):929. 
Beck, Ulrich. 1992 [German 1986]. The Risk Society: Towards A New Modernity. London: Sage.

1995. Ecological Enlightenment: Essays on the Politics of the Risk Society. Translated by Mark A. Ritter. Atlantic Highlands: NJ: Humanities Press.

1996. Risk society revisited: Theory, politics, and research programmes. Pp. 211-239 in Barbara Adams, Ulrich Beck, and Joost Van Loon, eds., The Risk Society and Beyond. London: Sage.

Bernhard, Bo and Frederick Preston. 2007. Introduction: Sociologies of problem gambling. American Behavioural Scientist 51(1):3-7.

Borrell, Jennifer. 2008. A thematic analysis identifying concepts of problem gambling agency: With preliminary exploration of discourses in selected industry and research documents. Journal of Gambling Issues 20:195218.

Borrell, Jennifer and Jacques Boulet. 2007. Values, objectivity, and bias in gambling research. Pp. 567-592 in Garry Smith, David C. Hodgins, and Robert J. Williams, eds., Research and Measurement Issues in Gambling Studies. London: Elsevier.

Campbell, Colin. 1987. The Romantic Ethic and the Spirit of Modern Consumerism. New York: Basil Blackwell.

Campbell, Colin, Garry J. Smith, and Timothy Hartnagel. 2005. The Legalization of Gambling and its Consequences: A Cross-National Comparison. . Ottawa: Law Commission of Canada.

Castellani, Brian. 2000. Pathological Gambling: The Making of a Medical Problem. Albany, NY: State University of New York Press.

Clotfelter, Charles. T. and Philip J. Cook. 1989. Selling Hope: State Lotteries in America. Cambridge, MA: Harvard University Press.

Collins, Alan F. 1996. The pathological gambler and the government of gambling. History of the Human Sciences 9(3):69-100.

Cosgrave, James F. and Thomas R. Klassen. 2001. Gambling against the state: The state and the legitimation of gambling. Current Sociology 4(5):1-22.

Cosgrave, James F. 2006. Gambling, risk, and late capitalism. Pp. 1-24 in James F. Cosgrave, ed., The Sociology of Risk and Gambling Reader. New York: Routledge.

2008. Goffman revisited: Action and character in the era of legalized gambling. International Journal of Criminology and Sociological Theory 1(1):80-96.

Cox, Brian J., Nancy Yu, Tracie Afifi, and Robert Ladouceur. 2005. A national survey of gambling problems in Canada. Canadian Journal of Psychiatry 50(4):213-217.

Delfabbro, Paul. 2004. The stubborn logic of regular gamblers: Obstacles and dilemmas in cognitive gambling research. Journal of Gambling Studies 20(1):1-21. 
Derevensky, Jeffrey. 2009. Youth gambling: A Canadian perspective. Pp. 192 220 in James F. Cosgrave and Thomas R. Klassen, eds., Casino State: Legalized Gambling in Canada. Toronto: University of Toronto Press.

Derevensky, Jeffrey L., Rina Gupta, Karen Hardoon, Laurie Dickson, and AnneElyse Deguire. 2003. Youth gambling: Some social policy issues. Pp. 239-257 in Gerda Reith, ed., Gambling: Who Wins? Who Loses? Amherst, NY: Prometheus Books.

Dickerson, Mark. 2004. Measurement and modeling of impaired control: Implications for policy. Proceedings of Insight Nova Scotia: International Problem Gambling Conference. Halifax, Nova Scotia.

Dickerson, Mark, John Haw, and Lee Shepherd. 2003. The Psychological Causes of Problem Gambling: A Longitudinal Study of At Risk Recreational EGM players. Report to the Casino Community Benefit Fund, Sydney, Australia.

Dixon, David. 1991. From Prohibition to Regulation: Bookmaking, Anti-gambling and the Law. Oxford: Clarendon Press.

Eadington, William R. 2002. Measuring costs from permitted gaming: Concepts and categories in evaluating gambling's consequences. Journal of Gambling Studies 19(2):185-212.

Eadington, William R. and Judy Cornelius. eds. 1997. Gambling: Public Policies and the Social Sciences. Reno, NV: Institute For The Study Of Gambling And Commercial Gaming, University Of Nevada.

Ewald, Francois. 2002. The return of Descartes's malicious demon: An outline of a philosophy of precaution. Pp. 273-301 in Tom Baker and Jonathan Simon, eds., Embracing Risk: The Changing Culture of Insurance and Responsibility. Chicago: The University of Chicago Press.

Foucault, Michel. 1977. Discipline and Punish: The Birth of the Prison. New York: Vintage.

1991. Governmentality. Pp. 87-104 in G. Burchell, C. Gordon, and P. Miller, eds., The Foucault Effect: Studies in Governmentality. Chicago: University of Chicago Press.

Gephart, Jr., Robert B. 2001. Safe Risk in Las Vegas. M@n@gement 4(3):141158.

Giddens, Anthony. 1990. The Consequences of Modernity. Cambridge: Polity Press.

1991. Modernity and Self-Identity. Palo Alto, CA: Stanford University Press.

Goffman, Erving. 1967. Where the action is. Pp. 149-270 in Interaction Ritual. Garden City, NY: Anchor Books.

Goodman, Robert. 1995. The Luck Business: The Devastating Consequences and Broken Promises of America's Gambling Explosion. New York: The Free Press. 
Grinols, Earl. 2003. Cutting the cards and craps: Right thinking about gambling economics. Pp. 67-87 in Gerda Reith, ed., Gambling: Who Wins? Who Loses? Amherst, NY: Prometheus Books.

Hacking, Ian. 2002. Making up people. Pp. 99-120 in Historical Ontology. Cambridge, MA: Harvard University Press.

2004. Between Michel Foucault and Erving Goffman: Between discourse in the abstract and face-to-face interaction. Economy and Society 33(3):277-302.

Hannigan, John. 1998. Fantasy City: Pleasure and Profit in the Postmodern Metropolis. New York: Routledge.

Kingma, Sytze. 1997. "Gaming is play, it should remain fun!”: The gaming complex, pleasure and addiction. Pp. 173-193 in Pekka Sulkunen, John Holmwood, Hilary Radner, and Gerhard Schulze, eds., Constructing The New Consumer Society. New York: St. Martin's Press.

2004. Gambling and the risk society: The liberalisation and legitimation crisis of gambling in the Netherlands. International Gambling Studies 4(1):47-67.

Lesieur, Henry. 1984. The Chase: Career of the Compulsive Gambler. Cambridge, MA: Shenkman Books.

Livingstone, Charles and Richard Woolley. 2007. Risky business: A few provocations on the regulation of electronic gaming machines. International Gambling Studies 7(3):361-376.

Lupton, Deborah. 1999. Risk. London: Routledge.

Lyng, Stephen, ed. 2005. Edgework: The Sociology of Risk-Taking. New York: Routledge.

McGowan, Virginia. 2004. How do we know what we know: Epistemic tensions in social and cultural research on gambling, 1980-2000. Journal of Gambling Issues 11. http://www.camh.net/egambling/issue11/jgi 11 mcgowan.html

McKenna, Peter. 2008. Terminal Damage: The Politics of VLTs in Atlantic Canada. Haliax, NS: Fernwood Press.

McMillen, Jan, ed. 1996. Gambling Cultures: Studies In History and Interpretation. London: Routledge.

Miller, Daniel. 1995. Consumption as the vanguard of history. Pp. 1-57 in Daniel Miller, ed., Acknowledging Consumption: A Review of New Studies. London: Routledge.

Mun, Wing Phil. 2002. Calculated risk-taking: The governance of casino gambling in Ontario. Ph.D Thesis, Graduate Department of the Centre of Criminology, University of Toronto.

Peele, Stanton. 2003. Is gambling an addiction like drug and alcohol addiction? Developing realistic and useful conceptions of compulsive gambling. Pp. 
208-218 in Gerda Reith, ed., Gambling: Who Wins? Who Loses? Amherst, NY: Prometheus Books.

Productivity Commission. 1999. Australia's Gambling Industries, Report No. 10. Canberra: AusInfo.

Reith, Gerda. 2005. On the edge: Drugs and the consumption of risk in late modernity. Pp. 227-247 in Stephen Lyng, ed., Edgework: The Sociology of Risk Taking. New York: Routledge. 2007. Gambling and the contradictions of consumption. American Behavioural Scientist 51(1):33-55.

2008. Reflections on responsibility. Journal of Gambling Issues 22:149155.

Responsible Gambling Council Ontario. 2002. It's Only a Game: The Responsible Gambling Handbook.

Ritzer, George. 1999. Enchanting a Disenchanted World: Revolutionizing the Means of Consumption. Thousand Oaks, CA: Pine Forge Press.

2005. Enchanting a Disenchanted World: Revolutionizing the Means of Consumption (2nd ed.). Thousand Oaks: Pine Forge Press.

Rose, I. Nelson. 2003. Gambling and the LawC: Status of Gambling Laws. www.gamblingandthelaw.com, August 3.

Rose, Nikolas. 1996. The death of the social? Re-figuring the territory of government. Economy and Society 25(3):327-356.

1999. Powers of Freedom: Reframing Political Thought. Cambridge: Cambridge University Press.

Shaffer, Howard. 2003. A critical view of pathological gambling and addiction: Comorbidity makes for syndromes and other strange bedfellows. Pp. 175-190 in Gerda Reith, ed., Gambling: Who Wins? Who Loses? Amherst NY: Prometheus Books.

2004. In celebration of the WAGER and Tom Cummings: Reflections on a seminal publication, The Wager 9(52). http://www.basisonline. org/2004/12/index.html

2007. Op-ed/editorials - The challenge of translating research to practice: Are we getting lost in translation? The Basis. http://www.basisonline.org/2007/01/index.html

Smith, Garry J. and Colin S. Campbell. 2007. Tensions and contentions: An examination of electronic gaming issues in Canada. American Behavioural Scientist 51(1):86-101.

Steel, Zachary and Alex Blaszczynski. 2002. Impulsivity, personality disorders and pathological gambling severity. Pp. 107-124 in J.J. Marotta, J.A. Cornelius, and W.R. Eadington, eds., The Downside: Problem and Pathological Gambling. Reno, NV: Institute for the Study of Gambling and Commercial Gaming

Tucker, David. M. 1991. The Decline of Thrift in America: Our Cultural Shift from Saving to Spending. New York: Praeger. 
Venn, Couze. 1984. The subject of psychology. Pp. 119-152 in Julian Henriques, Wendy Holloway, Cathy Urwin, Couze Venn and Valerie Walkerdine, eds., Changing the Subject: Psychology, social regulation and subjectivity. London: Methuen \& Co. Ltd.

Volberg, Rachel, W. Lamar Moore, Eugene M. Christiansen, Will E. Cummings, and Steven M. Banks. 1998. Unaffordable losses: Estimating the proportion of gambling revenues derived from problem gamblers. Gaming Law Review 2(4):349-360.

Volberg, Rachel. 2008. Book review: The Sociology of Risk and Gambling Reader. Journal of Gambling Issues (21): July.

Wardman, Dennis, Nady el-Guebaly, and David Hodgins. 2001. Problem and pathological gambling in North American Aboriginal populations: A review of the empirical literature. Journal of Gambling Studies 17(2):81100.

Weber, Max. 1958. The Protestant Ethic and the Spirit of Capitalism. Trans. Talcott Parsons. New York: Charles Scribners Sons.

Whyte, Keith. 2003. A public policy response to problem gambling. Pp. 268-274 in Gerda Reith, ed., Gambling: Who Wins? Who Loses? Amherst, NY: Prometheus Books.

Williams, Robert and Robert Wood. 2004. The Demographic Sources of Ontario Gaming Revenue: Final Report. Ontario Problem Gambling Research Centre.

2007. The proportion of Ontario gambling revenue derived from problem gamblers. Canadian Public Policy 33(3):367-387.

James F. Cosgrave is an Assistant Professor in the Department of Sociology at Trent University. His current research examines the state's role in the development of gambling markets. He is the co-editor of Casino State: Legalized Gambling in Canada (with Thomas Klassen), and the editor of The Sociology of Risk and Gambling Reader. He is presently co-authoring a book, with Patricia Cormack, which examines the place of the state in the everyday lives of Canadians. jimcosgrave@trentu.ca 